\title{
Early European interaction with Aboriginal hunters and gatherers on Kangaroo Island, South Australia
}

\author{
Philip A. Clarke
}

The earlier written history of European settlement in Australia generally portrays the Aboriginal inhabitants as being at best inconsequential or at worst a hindrance to the development of a Western nation. For instance, early this century, Blacket gave his impression of the role of Aboriginal people in the early years of European settlement in South Australia by saying 'These children of the bush...gave the early settlers much trouble.' $639582^{*} 1$ Similar opinions of South Australian history were later provided by Price and Gibbs. ${ }^{2}$ However, elsewhere modern scholars, such as Baker and Reynolds, are putting forward views that Aboriginal people had important roles in the setting up of the British colonies across Australia. ${ }^{3}$ They demonstrate that the contribution of Aboriginal people to the colonising process has been an underestimated aspect of Australian history. Following this argument, I am concerned here with assessing the importance of Aboriginal hunter/gatherer knowledge and technology to the early European settlement of South Australia. Kangaroo Island is where the first unofficial settlements were established by European sealers, who brought with them Aboriginal people from Tasmania, and obtained others from the adjacent coastal areas of South Australia. This is an important region for the study of the early phases of European interaction with Aboriginal people. Thus, this paper is primarily a discussion of how and what European settlers absorbed from Aboriginal people and their landscape. The period focussed upon is from the early nineteenth century to just after the foundation of the Colony of South Australia in 1836.

\section{European expansion into southern Australian waters}

In 1791, vessels returning to England from New South Wales took word of schools of whales in Australian waters. This set in train a rush by British and American whalers. ${ }^{4}$ The colonies in Australia offered whalers a chance to make a profit that they would not otherwise make if simply whaling, by taking cargo on the outward journey. By the early 1800 s, the worldwide marine industry was booming. Whales were a major source of oil

\footnotetext{
${ }^{1}$ Blacket 1911, p.163.

${ }^{2}$ Price 1924; Gibbs 1969.

${ }^{3}$ Baker 1989; Reynolds 1990.

${ }^{4}$ See Finney 1984, p.58. Starbuck (1878 [1964]) provides tables showing returns of whaling vessels sailing from American ports. From this it is clear that in the 1790s, the Pacific Ocean emerged as a major whaling area.
} 
used for candle wax, lamp fuel, lubricant and soap. ${ }^{5}$ The bone was also used as umbrella frames, hoops beneath dresses, stiffening corsets and for firing in potteries. Seal skins were required by merchants for trade in China, and for the fur-hat factories in England. ${ }^{6}$ Shoes in the Australian colonies were also sewn from seal skins. ${ }^{7}$ Whaling and sealing were such important parts of the early economy of New South Wales that Governor King attempted to restrict the operations of hunting crews in eastern Australia to those operating from his colony, in particular excluding those run by non-British interests. ${ }^{8}$ Because of this, foreign vessels were forced into concentrating on regions, such as southern Australia, that were at that time beyond colonial authority. European exploration, both official and unofficial, went hand in hand with economics.

Given the importance of marine industries to the Australian economy, it is not surprising that the first European settlers in South Australia were sealers and whalers. A small mixed population of European and Aboriginal people had grown in the region several decades prior to the formation of the Colony of South Australia in $1836 .{ }^{9}$ These were European men and their Aboriginal labour force, initially working out of Bass Strait and Van Diemen's Land (now called Tasmania). ${ }^{10}$ Known generally as Straitsmen, they represented a wide range of national and racial backgrounds, being castaways from whaling and sealing boats that were owned by American, British and French companies. Some of these vessels were possibly in southern Australian waters searching for seal colonies and whales at the same time as the first recorded European visit to South Australia by Matthew Flinders in 1802." Unoccupied islands, such as Kangaroo Island and those of Bass Strait, provided a safe haven to establish depots (Figure 1). ${ }^{12}$ Sealing was an activity that suited the small scale operations of European people living in fairly isolated conditions, as only the cured skin was required could be easily stored. The Straitsmen who eventually settled on Kangaroo Island became known simply as

\footnotetext{
${ }^{5}$ Newland 1921, pp.16,17, Hosking 1973, intro., p.3; Blainey 1977, p.99.

"The American merchant, Pendleton, was in southern Australian waters in 1803 seeking seal skins to sell in China (Cooper, 1952, p.173). Cumpston (1970, pp.3,29,104) has records of Australian seals being hunted for the Chinese market. See also Blainey 1977, p.99.

${ }^{7}$ Blainey 1977, p.106.

${ }^{8}$ Moore 1924, pp.83-86; Nunn 1989, p.19.

"In this paper, the white explorers and settlers are referred to as Europeans, although they would have seen themselves differently as English, French, American etc. Nunn (1989, pp.27-48) provides an account of the earliest European settlement on Kangaroo Island. "Detailed accounts are provided by Finnis nd; Nunn 1989; Plomley and Henley 1990. Caw thorne (1926) provides a fictional account of the whalers and sealers on Kangaroo Island. Cumpston (1970) has records for over 500 people who had visited Kangaroo Island before official settlement in 1836 .

"For accounts of the earliest European visitors to South Australia, see Flinders cited in Gill, 1909, pp.110-112, Moore 1924, pp.83-87; Blacket 1911, pp.11,12; Nunn 1989, p.11. R. Langdon (Advertiser, 29 December 1956) considered that American whalers may have been in South Australian waters in 1800. Flinders (cited in Cumpston, 1970, pp.6-14) thought the marks of a fire on Boston, Thistle and Kangaroo Islands may have been caused by an early visit by the French explorer La Perouse.

${ }^{12}$ The pre-European occupation of Kangaroo Island is discussed by Tindale 1937a,b; Tindale and Maegraith 1931; Lampert 1979; Draper 1988. The occupation of the islands in Bass Strait is discussed by Jones 1974. Also see Tindale 1974, Tribal Map.
} 
Islanders. These lawless people, living beyond colonial authority, have been described as the 'banditti of Bass Strait'.

With the growing scarcity of seals in Tasmanian waters during the second decade of the nineteenth century, sealers in the eastern colonies increasingly focused their attention on what were then outlying regions, such as southern South Australia. ${ }^{14}$ From about 1811, some Sydney-based sealers even went as far as Macquarie Island between Tasmania and the Antarctic Circle during the sealing season. ${ }^{15}$ In 1820 , there were an estimated fifty sealers, with about a hundred Aboriginal wives and children, living in the Bass Straits to Kangaroo Island region. ${ }^{16}$ At the South Australian end, colonies of the New Zealand fur seal (Arctocephalus fosteri) and the Australian sea lion (Neophoca cinerea) had been largely missed by the early wave of sealers. In 1830 , sealers were reported to be based on Thistle Island and other islands in Spencer Gulf. ${ }^{17}$ About this time, a sealer and his two Aboriginal wives and family lived on Saint Peter Island off Denial Bay on the western coast of Eyre Peninsula. ${ }^{18}$ Across the border of South Australia into Victoria, sealing stations were operating from 1828 at Portland Bay, also before the official settlement of that colony. ${ }^{19}$. In the early 1830 s, permanent whaling establishments were based on Kangaroo Island. ${ }^{20}$ In 1835, there were at least seventy six Australian ships engaged in deep-sea whaling from the eastern colonies. ${ }^{21}$ In South Australia, Europeans had ranged along much of the coastline before the official settlement of 1836 .

\section{Early European settlement on Kangaroo Island}

The first physical contact that Aboriginal people in the southern coastal regions of South Australia had with Europeans occurred with whalers and sealers based on Kangaroo Island. Here, European settlement began with a number of extended visits. Captain Isaac Pendleton, a New York whaler on the Union, wintered at American River on Kangaroo Island with his crew in 1803 while building another vessel, the Independence. ${ }^{22}$ Some months earlier he had been told about the advantages of the island during a chance meeting with French explorer Nicholas Baudin of Le Geographe

\footnotetext{
${ }^{13}$ Barwick 1985, p.185.

${ }^{14}$ Nunn 1989, p.22.

${ }^{15}$ Blainey 1977, p.106.

${ }^{16}$ Ryan 1981, p.69.

${ }^{17}$ Lieutenant Sleeman on the 'Dart' met a party of sealers on Thistle Island on the 8 or 9 April 1830 (cited in Gill, 1906, p.52). See other reports by J. Hart (cited in Moore, 1924, p.107); Sutherland (cited in Moore, 1924, p.121; Cumpston 1970, p.172). There was a whaling station still operating at Thistle Island in 1839 ('Report on Whaling in South Australia', Statistical Society of South Australia, 29 December 1841 [reprinted in the Proc. R. Geogr. Soc. Aust. S. Aust. Br., 1921, pp.25,26].

${ }^{18}$ The Australasian, 8 November 1902.

${ }^{19}$ Accounts of western Victorian sealing stations are provided by MacKenzie 1976, Blainey 1977, p.112; Barwick 1985, pp.189-190,207,208; Plomley and Henley 1990, p.9.

${ }^{21}$ Nunn 1989, p.45.

${ }^{21}$ Blainey 1977, p.107.

${ }^{22}$ Cumpston 1970, pp.27,50,85.
} 
Figure 1 Possible whale movements and the distribution of whaling stations in southern South Australia prior to 1836 (after Clarke, 1994).

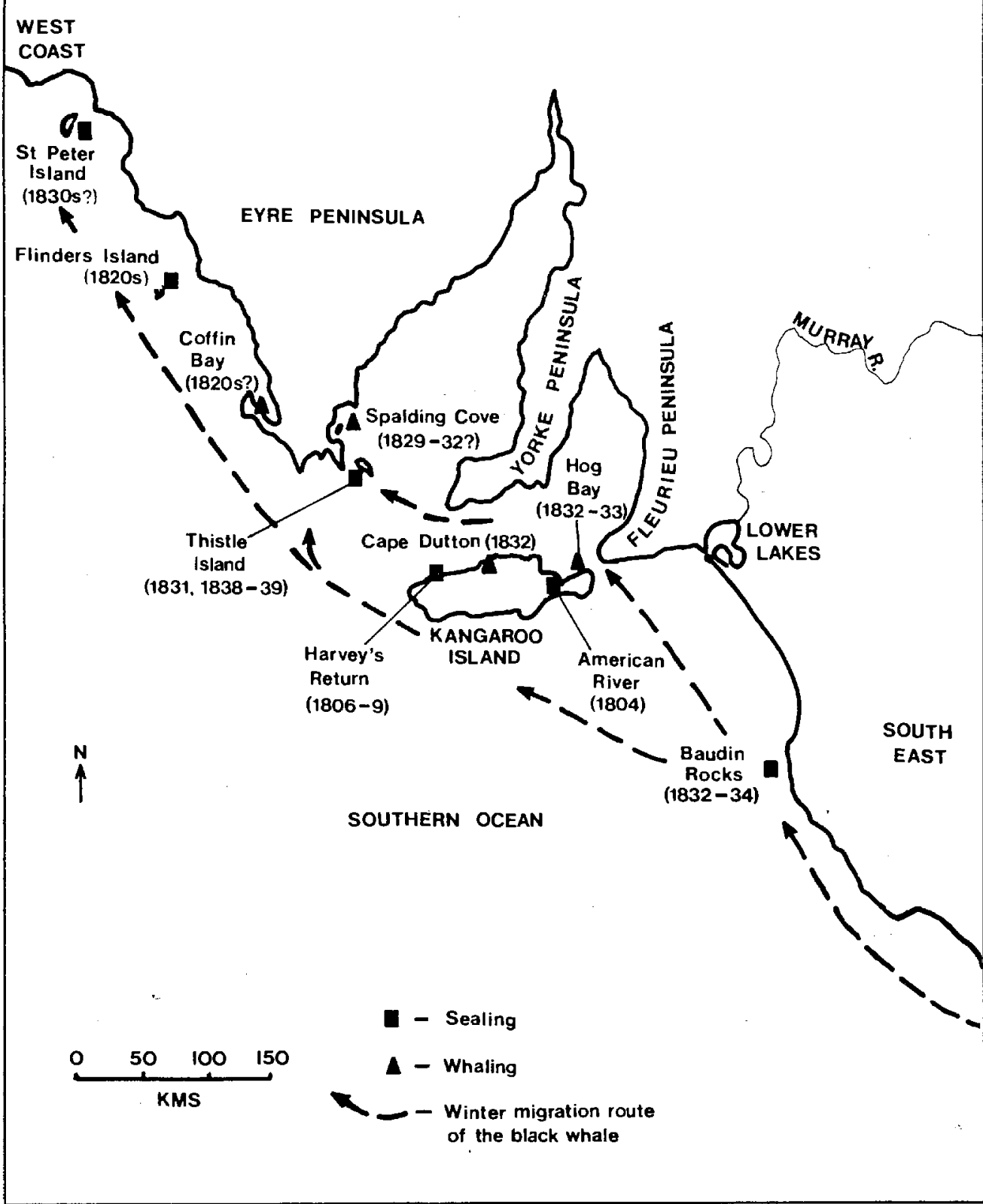


at King George Sound in Western Australia. ${ }^{23}$ The first long term stay on Kangaroo Island by Europeans was possibly by Joseph Murrell, put in charge of a gang of six sealers at Harvey's Return in $1806 .{ }^{24}$ Their time there was longer than they had anticipated; they had to exist almost entirely on wild animal meat until the men were found three years later. The value of previously uninhabited islands, such as Kangaroo Island, is shown by the fact that Murrell and his crew are believed to have been later killed by Aboriginal people when their boat was wrecked on the coast of New South Wales in 1816. ${ }^{25}$ Another early resident of Kangaroo Island was Robert Newman, who arrived there about $1814 .^{26}$ A visitor to Kangaroo Island was Peter Dillon, who collected salt from December 1815 to March $1816 .{ }^{27}$ One of his crew was Thompson, reportedly a Portuguese man who had previously been on Kangaroo Island and nearby islands for seven years. In 1817, Hammond reported that thirteen Europeans had been living on Kangaroo Island, subsisting on wild birds. ${ }^{28}$ George Fifer was another European reportedly living on the island in $1817 .{ }^{29}$ However, the details of how and where on Kangaroo Island these early settlers lived are generally poorly known.

Kangaroo Island's first permanent European residents arrived in 1819, among them George Bates and the self-styled 'Governor' Henry Wallen. ${ }^{30}$ The Islanders lived chiefly in the north eastern part of Kangaroo Island. This section of coastline provided a refuge from the fierce southern seas that lashed the south coast of the island. ${ }^{31}$ From their bases on Kangaroo Island, the men in their whale boats were able to visit sealing colonies that were located at places such as Thistle Island in Saint Vincent Gulf. ${ }^{32}$ The Islander community that developed comprised men who had shunned mainstream society, particularly sailors who had 'jumped ship'.

As the whaling and sealing industry in the southern seas grew, Kangaroo Island became a major stopping point for all vessels in the area. The island was useful to passing ships for replenishing supplies of fish and kangaroo meat, fresh water for drinking, and wood for burning. ${ }^{33}$ For those who became established on Kangaroo Island, trade from passing ships was based on island products such as animal oil, whale bone, animal skins and fresh vegetables. Skins in particular, were a major product of the island. For instance, a Captain Hart, who frequently traded with the Islanders, took

\footnotetext{
${ }^{23}$ Plomley and Henley 1990, pp.6,7.

${ }^{24}$ Finnis nd; Kostoglou and McCarthy 1991, p.58.

${ }^{25}$ Nunn 1989, p.23.

${ }^{26}$ Plomley and Henley 1990, p.13.

${ }^{27}$ Cumpston 1970, pp.39,40.

${ }^{28}$ Sydney Gazette, 15 April 1817.

${ }^{29}$ Plomley and Henley 1990, p.13.

${ }^{311}$ Accounts of Bates ('Fireball Bates') and Wallen (variously known as Walley, Waller,

Warlans, Warland and Wharley) are given by Leigh 1839, pp.123-126; Bull 1884, p.5; Tolmer 1882, vol.1, p.318; vol.2, p.7); Finnis nd; Cumpston 1970. Bull's dates of arrival differ from other sources, suggesting that Bates came to Kangaroo Island much later than Wallen, in 1824 not 1819.

${ }^{31}$ See an account of the climate of Kangaroo Island given by Burrows 1979. Cumpston (1970, pp.40,50,52,70,165-166) provides early accounts.

${ }_{32}$ Advertiser, 27 December 1886.

${ }^{33}$ Early resources of Kangaroo Island are discussed by E.L. Bates cited in Kingscote Country Women's Association, nd, p.23; Osterstock 1975, p.36.
} 
away 7,000 skins in $1832 .{ }^{34}$ Salt was another early export from Kangaroo Island. ${ }^{35}$ From ships passing through, the Islanders obtained a variety of consumer articles, such as alcohol and tobacco. Some runaway convicts found their way to the southern sealer settlements where they sought a passage from passing boats. ${ }^{36}$ Kangaroo Island was effectively an unofficial outstation of Van Diemen's Land (settled in 1803). Many of the vessels stopping at Kangaroo Island were on the way to or from Launceston or Hobart.

\section{Aboriginal occupation of Kangaroo Island}

Although Australia's second largest offshore island, and a mere fourteen kilometres by sea from the mainland, Kangaroo Island does not appear to have been occupied by Aboriginal people for some time prior to European settlement. In 1802, when English explorer Matthew Flinders visited Kangaroo Island, it was surmised that the place was uninhabited due to the absence of smoke and the tameness of seals and kangaroos. ${ }^{37}$ In the following year, French explorer, Nicholas Baudin, visited the island, which he called Ile Decres. Baudin was accompanied by a team of zoologists, among them Francois Peron. In the account provided by Peron, he supports Flinders' assertion by saying 'No trace of man's stay here can be discerned on the shores... ${ }^{38}$ We must therefore assume that Kangaroo Island was uninhabited by Aboriginal groups at the time of the first recorded visits by Europeans. In contrast, the mainland opposite the island was perhaps one of the most heavily populated regions of Australia.

Due to the geographical and social isolation of living on remote islands, there were no European women in the early settlements of sealers. This created a high demand amongst the Islanders for Aboriginal women (Figure 2). Some of the captains of trading vessels, knowing this, brought with them captured Aboriginal women to be traded for goods with the Islanders. One report says 'the traders, who visited the island occasionally, brought them a Tasmanian lubra for a consideration'. ${ }^{39}$ Some of these women had evidently been obtained from their Aboriginal husbands in Tasmania, exchanged for the skinned carcases of seals. ${ }^{40}$ It is likely that the first women on Kangaroo Island in the historic period were Tasmanians, reflecting the early historical connection between southern South Australia and Tasmania.

In spite of some movement of Tasmanian women to Kangaroo Island, the Islander's desire for wives eventually led to excursions to adjacent mainland regions. In

\footnotetext{
${ }^{34} \mathrm{G}$. Bates in Observer, 14 September 1895. Captain Hart became a successful merchant and politician in South Australia. He was premier of the colony on three occasions (Blacket, 1911, pp.431,432).

${ }^{35}$ Observer, 15 January 1898 and 20 May 1899. This trade in salt was still going on in 1844

(Southern Australian, 24 September 1844).

${ }^{36}$ Plomley and Henley 1990, p.20.

${ }^{37}$ Flinders 1814.

${ }^{33}$ Peron 1816 [1979, p.181].

${ }^{34}$ Advertiser, 20 March 1880.

${ }^{41}$ Cumpston 1970, p.56; Ryan 1981, pp.67-69.
} 


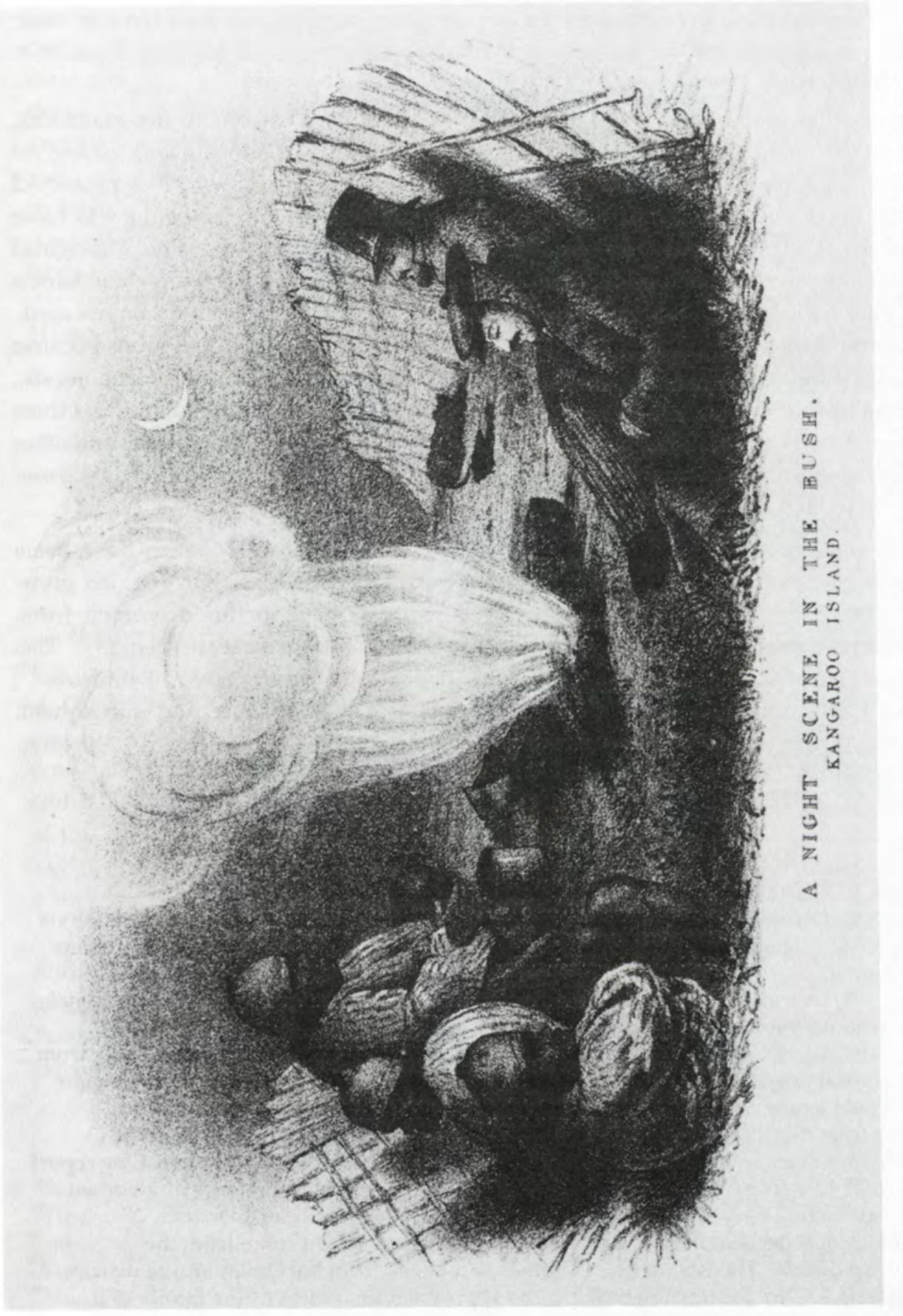

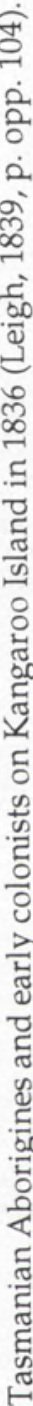

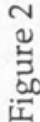


1819, it was reported by a passing ship captain that there were several Europeans living on the island who:

have carried their daring acts to an extreme, venturing on the mainland in their boats and seizing on the natives, particularly the women, and keeping them in a state of slavery, cruelly treating them on every trifling occasion.

On one expedition to obtain wives, a party of five Islanders crossed to the mainland, leaving two Aboriginal women, whom they had already caught, hunting and fishing on the island. ${ }^{42}$ Landing at Cape Jervis, probably on the northern side which is protected from both the prevailing winds and the heavy swell, they walked across country to Lake Alexandrina. Their method of capture was to wait until morning, when the Aboriginal men had gone hunting, and then rush in, grabbing the women and tying their hands behind their backs. Back at Hog Bay on Kangaroo Island, the women would be released. As the marauding trips grew in frequency, the mainland Aboriginal populations became more wary, and the risk to the Islanders increased. On one trip to Cape Jervis, Aboriginal people waited until the Islanders were about five kilometres inland and then attacked. ${ }^{43}$ One Islander was speared in the foot, but escaped with a slight wound. The stories of Islander raids on the mainland populations have been enshrined in Lower Murray mythology.

Although the earliest known woman on Kangaroo Island appears to have been Tasmanian, the number of women there from coastal South Australian regions grew steadily. The core Aboriginal population on Kangaroo Island included women from Eyre Peninsula, the Lower Murray, and the Cape Jervis to Adelaide Plains region. ${ }^{45}$ The population may also have occasionally included people from Yorke Peninsula. ${ }^{46}$ However badly treated the women were, the mode of their capture and subsequent treatment, appears to have much in common with Aboriginal practices in the preEuropean period. ${ }^{47}$

\footnotetext{
${ }^{41}$ Sutherland cited in Moore, 1924, p.121.

${ }^{42}$ Advertiser, 27 December 1886.

${ }^{43}$ Advertiser, 27 December 1886. Basedow (1914, p.161) has an account of another Cape Jervis expedition from Kangaroo Island to capture women which involves the 'runaway whalers', George Horman and Pirkey.

${ }^{44} \mathrm{Clarke}(1997)$ provides an analysis of Aboriginal and European accounts of an Aboriginal woman escaping the sealers on Kangaroo Island by swimming the Backstairs Passage.

${ }^{45}$ Tindale (1937a, p.32) suggests that long time island resident, Little Sal, was originally from the Port Lincoln area. Emma, the wife of John Anderson, was said to be from Port Lincoln (Plomley and Henley, 1990, pp.34,76-77). Also, Kal.loon.goo (Sarah, Charlotte) was reportedly from this location (Plomley and Henley, 1990, pp.43,77). The Perth Gazette (3 October 1835) has an account of Port Lincoln women being abducted by whalers. One report (Advertiser, 27 December 1886) mentions that Islanders regarded the Port Lincoln women they stole as 'having fiery and determined tempers.' Another account (Advertiser, 27 December 1886) states that most of the women on Kangaroo Island came from the Onkaparinga district. The Islander Nat Thomas had a wife from the Onkaparinga district (Bull, 1884, pp.32-36). Kartinyeri (1990, pp.13,14) provides an outline of the family of a Kangaroo Island sealer named Wilkins and his Aboriginal wife who was reputed to have originally been from the Adelaide area.

"Kuhn and Fowler (1886, p.143) claim that 'the Blacks relate that it [Yorke Peninsula] had occasionally been visited by sealers' prior to the first settlement there in 1847.

${ }^{47}$ Wilkinson 1848, pp.329,330; Thomas 1925, pp.72,118.
} 
On Kangaroo Island, the Tasmanian women and their children appear not to have mixed well with Aboriginal people from the South Australian mainland. For instance, the Tasmanians on Kangaroo Island apparently considered that their own hunting and gathering skills were superior to that of all others. ${ }^{48}$ For this reason, these women and their children generally went on expeditions alone. The Tasmanians apparently retained the use of their language, some words of which were still known by their descendants during Tindale's fieldwork there in the $1930 \mathrm{~s} .{ }^{49}$ The total population of Kangaroo Island was estimated at about two hundred people in 1826, although this figure probably includes all the men working on boats in the southern coastal region of South Australia. ${ }^{50}$ The Aboriginal women had important roles on the island, acting as labourers, hunters, wives, trackers, garment makers and food gatherers.

\section{Hunting and gathering technology on Kangaroo Island}

Reports on Islander lifestyle from passing ship captains and early colonists, indicate that it was considered to have had much in common with that of the Aboriginal people. For instance, in 1819 it was reported by Sutherland that there were several Europeans living on Kangaroo Island who were like:

complete savages, living in bark huts like the natives, not cultivating anything, but living entirely on kangaroos, emus and small porcupines, and getting spirits and tobacco in barter for the skins which they lay up during the sealing season. They dress in kangaroo skins without linen, and wear sandals made from sealskins. They smell like foxes."

The boots of these Islanders were also sometimes made from wallaby skins. ${ }_{53}^{52}$ Their cloaks consisted of a number of skins stitched together in Aboriginal fashion. ${ }^{53}$ One report from a colonist arriving at Kangaroo Island and meeting Islanders for the first time said 'The two islanders-clothed in opossum skin shirts, and with coats, trousers, and boots made of the skin of the red kangaroo-were mistaken for savage inhabitants of the new country. ${ }^{54}$ The sealer's practice of having several Aboriginal wives would have strengthened the first assumptions of official colonists that the Islanders were all Aboriginal people.

Islander subsistence relied heavily on the hunting and gathering skills of their Aboriginal work force, as agriculture was not extensively practised until after later official settlement. In 1819, after Bates and Wallen had occupied Kangaroo Island, a Tasmanian woman named Dinah proved of 'greatest value to them in their hunting expeditions through the scrub. ${ }^{55}$ Sealing was also an activity in which the Tasmanian

\footnotetext{
${ }^{48}$ Basedow 1914, p.161.

${ }^{44}$ Tindale $1937 \mathrm{a}$, p.36.

${ }^{50}$ Australian, 9 March 1826.

${ }^{51}$ Sutherland cited in Moore, 1924, p.121.

${ }^{52}$ Nunn 1989, p.83.

${ }^{53}$ Hobart Town Gazette, 12 June 1826 . This description compares well with a Yorke Peninsula wallaby skin cloak (A6409 in the South Australian Museum.

${ }^{54}$ Advertiser, 27 December 1886. The Hobart Town Gazette, 12 June 1826, has another account of 'savages' on Kangaroo Island.

${ }^{55}$ Advertiser, 27 December 1886.
} 
women were able to use skills from their homeland. ${ }^{56}$ An Aboriginal woman, originally from the mainland, was in the habit of always carrying a 'peculiar' shaped club with her for hunting. ${ }^{57}$ The skins of kangaroos, wallabies and seals were important commodities for island trade. In 1831, it was recorded that the sixteen to eighteen men living on Kangaroo Island were in the practice of gathering on a certain day once a year at Nepean Bay to barter their skins to traders (Figure 3). ${ }^{58}$ The reliance that some Islanders had upon the hunting efforts of the Aboriginal women continued long after official settlement in 1836 . $^{5}$

The Kangaroo Island flora and fauna had much in common with coastal southern Australia and Tasmania. ${ }^{60}$ This would have enabled the Aboriginal women brought there to transfer easily their previously acquired hunting and gathering skills. During the early years of European occupation of Kangaroo Island and other nearby islands, the familiarity with the Australian landscape possessed by the women gave them greater access than Europeans to the natural resources of the island. To capture wallabies, the Aboriginal women on Kangaroo Island made hunting nooses. ${ }^{61}$ These were necessary, as it was difficult to use firearms for the capture of animals, such as marsupials, hiding in the dense thickets of Kangaroo Island. The nooses were about $46 \mathrm{cms}$ long, with the string woven from canvas thread. Each noose was stretched onto two small forked sticks put across wallaby pads to catch the head of an animal, choking it to death. The women checked these traps at sunrise, usually returning with the carcases around nine or ten o'clock in the morning. The wallabies were skinned, the pelts stretched on wire or stick hoops, then bundled into lots of fifty. The tails were boiled, the skin scraped off, and then cooked in ashes before being eaten. The sinews drawn from the tails were used to sew wallaby skins into rugs and coats.

Trips in whale boats were made by Islanders to collect eggs of the 'mutton bird' on Althorpe Island, and to kill seals in the caverns along the Kangaroo Island coast. ${ }^{62}$ Mutton-birding was apparently a practice that sealers in Bass Strait had gained from Aboriginal women when seals became scarce. ${ }^{63}$ In 1838, when some whalers were stranded in the Rivoli Bay district of the South East of South Australia, they invited 'pretty girls' from the local Aboriginal community to row with them in a boat to Penguin Rock to catch fat birds that frequented that spot. ${ }^{64}$ Wild pigs were another source of food. It seems likely that pigs existed on Kangaroo Island as early as 1803,

\footnotetext{
${ }^{56}$ Plomley and Henley (1990, p.19) provide an account of the seal hunting techniques used by Tasmanian Aboriginal women along the eastern coast of Tasmania.

${ }^{57}$ News, 17 March 1932.

${ }^{54}$ Griffiths cited in Cumpston, 1970, p.104.

${ }^{54} \mathrm{~A}$. Tolmer in the Southern Australian, 24 September 1844 reprinted Observer, 28 September 1844.

"Compare Tyler et al 1979 for Kangaroo Island with Hiatt 1967-68, Jones 1974, pp.319-354; Ryan 1981 for Tasmania.

"Leigh 1839, p.104; Cumpston 1970, p.172; Nunn 1989, p.84.

${ }^{62} \mathrm{The}$ 'mutton bird' referred to here is probably the short-tailed shearwater (Puffinus tenuirostris) or a related species. Reudiger (1980, p.53) refers to seal hunting.

${ }^{63}$ Ryan 1981, p.70.

${ }^{17}$ Stewart cited in McCourt and Mincham, 1977, pp.78,79.
} 


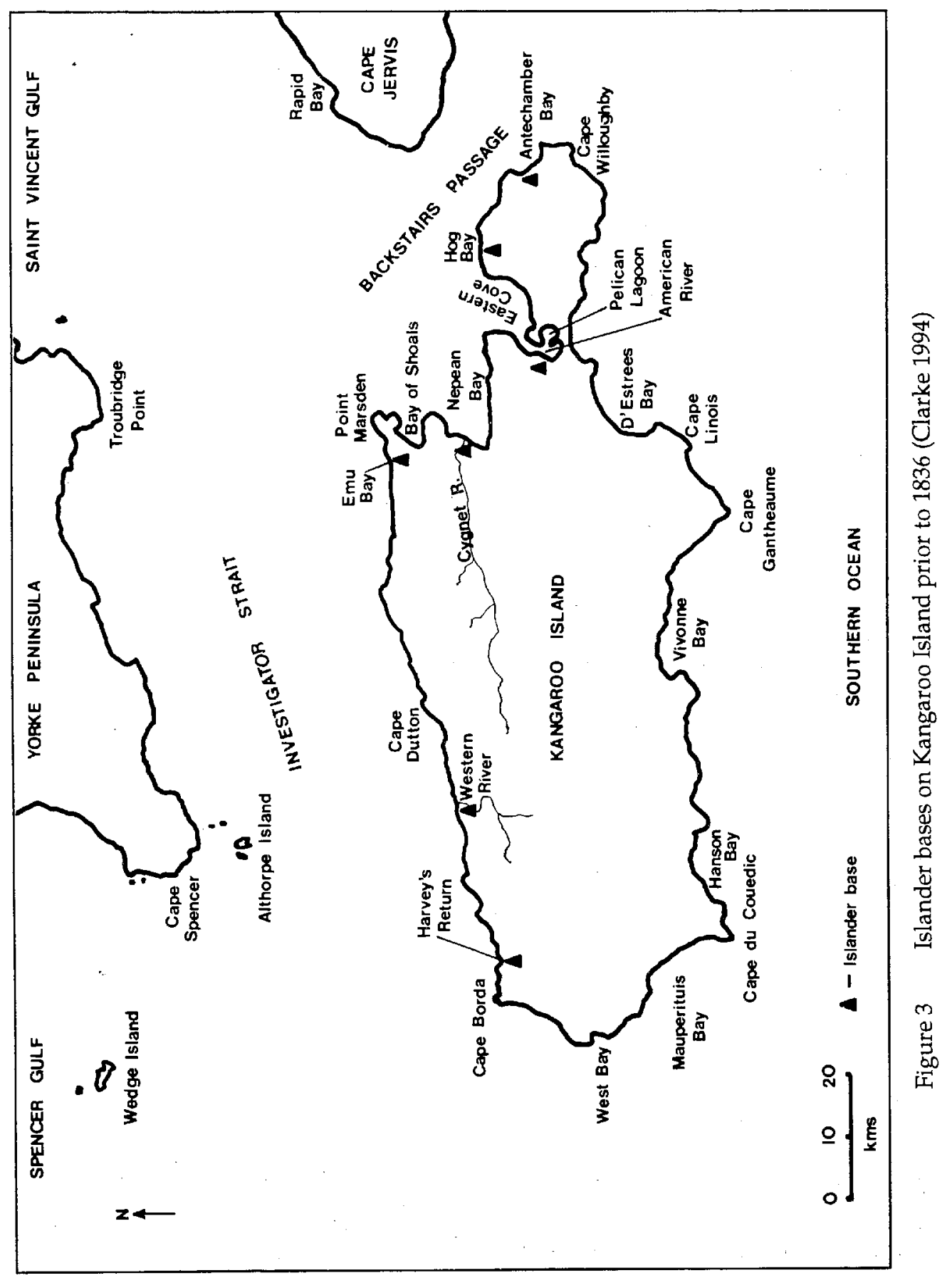


after the introduction of a boar and sow by Baudin. ${ }^{65}$ A passenger of the Cygnet, which arrived at Kangaroo Island with settlers in 1836, remarked that the sealers used ti-tree leaves as a tea supplement. ${ }^{66} \mathrm{~A}$ 'bush tea tree' was also used as a medicine to 'purify' the blood. ${ }^{67}$ Indigenous fruits were made by Islanders into puddings and jam. ${ }^{68}$ One of Wallen's wives reportedly used medicinal and sorcery objects such as stone charms. ${ }^{69}$ With the aid of the Aboriginal people, the natural environment provided the Islanders with most of their basic needs.

The Aboriginal women on Kangaroo Island retained some of their preferences for certain types of food, some of which Europeans would probably not have utilised. For instance, one early visitor to the island, who was taken on a duck hunting expedition near Cygnet River, reported:

They had come to a clearing in the scrub where they saw some large ant-hills which were broken into pieces. The newcomer soon learnt the reason for this, as he watched the lubras in the party make quickly for other termite nests from which they broke off large lumps, then shake out the teeming ants into each other's hands cupped together. They squeezed the crawling insects into a ball, and with much laughter and evident enjoyment, conveyed them to their mouths and munched them up.

Another example is provided by a resident who claimed that an Aboriginal woman on the island, probably not Tasmanian, had 'grizzled' hair in which she carried grubs, her great delicacy. ${ }^{71}$ The women, who in Aboriginal fashion generally went on expeditions without the men, were not restricted to the sheltered northern parts where the Islanders in the main based themselves. The Aboriginal women often went on extended expeditions along the southern coast where kangaroos, wallabies, possums, fish and shellfish were found in abundance. ${ }^{72}$ In 1869, there were still three Tasmanian women on Kangaroo Island who lived 'by their wits and their waddies', preferring to hunt for themselves rather than to accept government rations. ${ }^{73}$ The use of Aboriginal stone technology by the Islander population is well illustrated by the existence of archaeological remains of Tasmanian-type stone artefacts at their former campsites around the island (Figure 4$).^{74}$

\footnotetext{
${ }^{45}$ Bull (1884, p.10) records that the pigs found by sealers at Hog Bay had been left by the French. Cooper (1954) put forth the theory that Kangaroo Island pigs were introduced by Baudin. Nevertheless, Bates (cited Observer, 14 September 1895) claimed that the first pig was put on the island in 1832 .

"Anonymous cited in Gill, 1909, p.117.

${ }^{67}$ Observer, 28 September 1844.

${ }^{t *}$ Ibid.

"Leigh 1839, pp.160,161.

${ }^{70}$ Wells 1978, p.27.

${ }^{71}$ News, 17 March 1932.

${ }^{n}$ Basedow 1914, p.161.

${ }^{73}$ Register, 6 April 1869.

${ }^{74}$ Tindale 1937a, pp.32-36, plate 3. Some of these artefacts are housed in the Archaeology Collection of the South Australian Museum. Harvey (1941, p.367) refers to the implements made by the Tasmanian women brought to Kangaroo Island by sealers as part of the Newer Tasmanian Industries', with strong similarities to relatively recent material from north western Tasmania.
} 
Figure 4 South Australian Museum display panel, 'Evidences of Early $19^{\text {th }}$ Century Occupation of Kangaroo Island' from the 1930s: a,d,e-flint tools; b—food remains; c-handmade domino piece; $\mathrm{d}$-marsupial jaw bone tool.
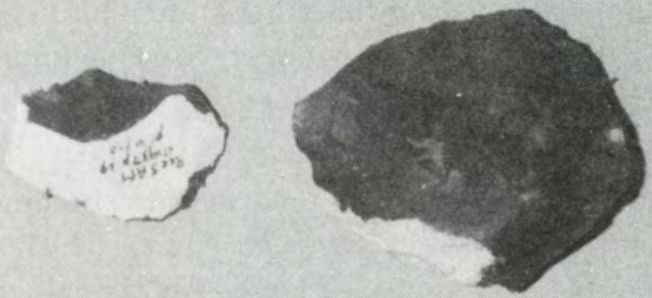

a
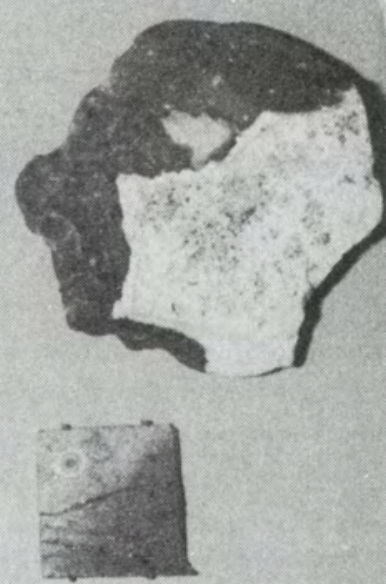

C

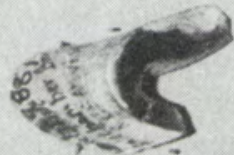

d

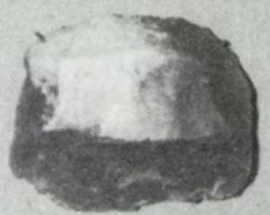

e

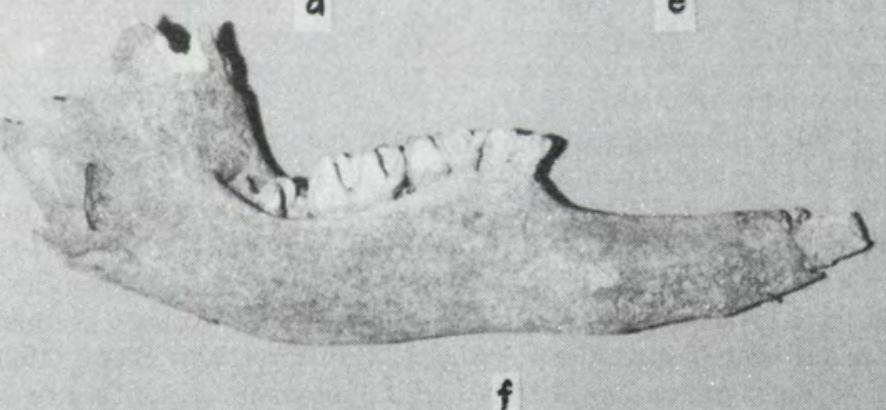


The dominance of the Aboriginal mode of subsistence is evident in the seasonal patterns of early life on Kangaroo Island. In 1826, a report on the Islanders said that 'When the fishing season for seals is over, these men, with the native women and their offspring, amounting in all to about 40 , retire into a valley in the interior of the island, where they have a garden and huts. ${ }^{75}$ The movement of the Islanders away from the coast during autumn was to avoid the fierce winter weather along the coast. Their summertime activities included hunting seal pups and collecting mutton bird eggs. Both types of animal breed in summer months. ${ }^{76}$ This summer/coast-winter/inland movement of people was similar to the pre-European movements of coastal Aboriginal people of Tasmania and southern South Australia.

The reliance upon Aboriginal hunters increased with time, as game became scarce from over exploitation. The last Kangaroo Island emu (Dromaius minor), which differed physically from the mainland species, was reportedly killed by the Aboriginal wife of an Islander several years before official settlement. ${ }^{78}$ The kangaroos and wallabies eventually retreated back into the thick scrub, making hunting by shooting difficult. ${ }^{79}$ The settlers arriving on Kangaroo Island in 1836 noted the apparent absence of the animal after which the place was named. ${ }^{80}$ The Kangaroo Island kangaroo (Macropus fuliginosus fulinginosus) had been hunted down to numbers so low that it was still considered extinct earlier this century. ${ }^{81}$ Although the density of people actually living on Kangaroo Island was low, the pre-1836 inhabitants nevertheless made their mark upon the landscape. When the official settlers arrived in the newly proclaimed colony of South Australia, the region had already suffered an ecological disaster due to European and Aboriginal activity on Kangaroo Island.

The important economic role of Aboriginal people on Kangaroo Island in the precolonial years is noted by many sources commenting on Islander life. ${ }^{82}$ Although the Aboriginal captives, whether from Tasmania or the mainland, were just as new to Kangaroo Island as the whalers and sealers, they quickly developed a close relationship with the island's landscape. In the 1870s, there was evidently a site on the island that

\footnotetext{
${ }^{75}$ Hobart Town Gazette cited in Finnis, nd.

${ }^{76}$ Plomley and Henley (1990) discuss the seasonal aspects of sealing. Ryan (1981, p.70) says that mutton bird egging was a late summer activity in the Bass Straits.

${ }^{77}$ Clarke (1991; Ellis (1976) provide accounts of Aboriginal movements in the Adelaide area;

Foster 1983 for the Lower South East; and Hiatt 1967-68 for Tasmania.

${ }^{78} \mathrm{R}$. Mongomery Martin cited in Moore, 1924, p.114. Blakers et al (1984, p.2) provides a historical account of the emu. The South Australian Museum has on display a reconstruction of what the Kangaroo Island emu looked like (Register, 12 February 1926). Slater (1978, p.14) claims that the last Kangaroo Island emu probably died in the possession of Empress Josephine of France in 1822, having being given two of the three live emus that were brought back by Peron. However, the record of R. Mongomery Martin would put the extinction of this species closer to the early 1830 s.

${ }^{74}$ Nunn 1989, p.55.

${ }^{8 ! 1}$ Dutton 1960, p.172.

${ }^{81} \mathrm{G}$. Bates (cited Observer, 14 September 1895) blames bushfires and hunting for the depletion of marsupial numbers. Wood Jones (1923-1925, pp.257-261) reports on the 'extinct' status of the Kangaroo Island kangaroo. However, this species survived and is once again common (Strahan, 1983, pp.248,249).

${ }^{82}$ One report (Advertiser, 27 December 1886) claims that Aboriginal women did much of the manual work on Kangaroo Island.
} 
local inhabitants still referred to as 'the old black woman's potato-ground' ${ }^{83}$ Whether this refers to a spot where yams were collected, or a place where potatoes were grown is not known. In all food-gathering activities, the labour and skills provided by Aboriginal women were significant.

\section{The relationship between Islanders and mainland Aboriginal people}

Some of the early encounters between the sealers and mainland Aboriginal groups were violent, and yet there is evidence that the relationship between them was complex. The violent clashes described above during the Islander expeditions to obtain wives, were balanced by the amicable relations that allowed the early employment of Aboriginal people in sealing activities. For instance, in June 1833 the sealer John Jones sailed from Launceston in the Henry, reaching Kangaroo Island in July:

He met a tribe of natives on Cape Jervis, consisting of ten families. Five of the men worked for him occasionally, and two were with him constantly for near five months. They were very useful, and willing to work for a trifling remuneration. To the two who remained with him long he gave pistols, powder, and shot; to the others slop-clothing. He saw their women and children only at a distance, and saw no other natives on the rest of the coast along Gulf St. Vincent; but their fires were very numerous.

Even at this early time, Aboriginal people were being incorporated into the world economy through their participation in the marine industries controlled from the northern hemisphere. Aboriginal people in the Cape Jervis area, through their interaction with the Islanders, were the first Aboriginal groups in South Australia to gain experience of Europeans.

A European who worked north along the Fleurieu Peninsula coastline before official settlement was Meredith, a Kangaroo Island-based sealer. He arrived at Kangaroo Island with another sealer, Jacobs, about $1827 .{ }^{85}$ In 1835 , despite advice from other Islanders, he moved to the Yankalilla district along Saint Vincent Gulf. He had with him an Aboriginal team, consisting of a Tasmanian woman named Sal and two male Aboriginal youths from the mainland. Sal was his wife and the youths were being trained to assist in the sealing activities of the Islanders. However, they eventually killed Meredith, using his boat for their own hunting and gathering expeditions along the coast. The Islanders then feared being attacked by Aboriginal people from the mainland, due to a threat by an Aboriginal man named 'Encounter Bay Bob' that he was going to cross to the island in the boat and kill all the white people. Eventually the boat concerned came adrift and was destroyed. The killing of Meredith was further proof that the prudence of the sealers in basing their activities on previously uninhabited parts of the landscape, such as Kangaroo Island, was well founded.

\footnotetext{
${ }^{83}$ Observer, 13 April 1870 .

${ }^{84}$ Jones 1835 [1921, p.74].

${ }^{\mathrm{Hs}}$ Meredith was based at Western River on Kangaroo Island (Cumpston, 1970, p.119). An account of Meredith and Big Sal is given by Leigh (1839, pp.155-157; Thomas Willson Observer, 7 October 1871. Barwick (1985, p.231) incorrectly assumes that Meredith was murdered near Port Lincoln. See also Bull 1884, p.6; Tolmer 1882, vol.2, pp.6-8; Plomley and Henley 1990, p.54.
} 
Some encounters between Islanders and Aboriginal groups from the mainland indicate the partial integration of the sealers into Aboriginal society. For instance, on one visit to the mainland, the Islander Bates assisted an Aboriginal man with a spear protruding from his stomach. ${ }^{86} \mathrm{He}$ cut out the spearhead, sewing up the wound. The victim apparently recovered soon afterwards. On a longer stay on the mainland, Bates was 'made a member of the tribe by being thrown on his back, and having all the males jump on his body in succession'. ${ }^{87}$ This appears to be a form of initiation ritual. Another Islander, Wallen, participated in the mourning ceremonies of Aboriginal people on one visit to the mainland. ${ }^{88}$ Through their possession of Aboriginal wives from the local groups and their involvement in ceremonial life, these Islanders were therefore to some extent incorporated into the Aboriginal kinship system.

In the period before 1836, some Aboriginal people from the mainland travelled widely. For example, an old Aboriginal man from the Cape Jervis 'tribe' was taken over to Kangaroo Island with his son, and later returned. ${ }^{89}$ Other Aboriginal people, such as Condoy and his niece Sally from Cape Jervis, also made early trips to the island. ${ }^{90}$ The latter was part of a crew on a sealing vessel in 1828 at King George Sound in Western Australia, along with another Cape Jervis person, Harry, and two Tasmanians, Dinah and Mooney. ${ }^{91}$ In 1831, Robinson noted there were Aboriginal women from Kangaroo Island in the sealing stations of the Kent Group in the eastern end of Bass Strait. ${ }^{92}$ Similarly, two Port Lincoln women were reportedly on Gun Carriage Island, a small island between Flinders and Cape Barren Islands in the Furneaux Group. ${ }^{93}$ This early movement of Aboriginal people would have broadened their experience with other Aboriginal cultures and given them greater knowledge of the geography beyond their own cultural boundaries.

The sealers living on Kangaroo Island appear to have had the best relations with the people from the Cape Jervis region, probably because this area was their chief landing spot on the mainland. Due to the treacherous nature of the seas off the southern coast of Fleurieu Peninsula, only the coastline sheltered by Kangaroo Island itself was safe for crossing in small boats. When the Islanders travelled to the Lower Lakes, this was primarily done across country from here, along the Inman Valley. Sturt's published map of the region in 1833, highlights the openness of this valley in contrast to the rugged southern coastline of Fleurieu Peninsula (Figure 5). Some of the Aboriginal men from the Cape Jervis district eventually became whalers who worked in the Encounter Bay area after official settlement. ${ }^{94}$ In general, the Aboriginal people in this part of

\footnotetext{
${ }^{86}$ E.L. Bates cited in Kingscote Country Women's Association, nd., p.23.

${ }^{87}$ Advertiser, 27 December 1886.

${ }^{84}$ Leigh 1839 , p.160.

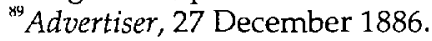

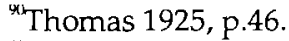

${ }^{41}$ Cumpston 1970, p.87.

${ }^{42}$ Robinson cited in Plomley, 1966, pp.338,339.

${ }^{93}$ Barwick 1985, pp.211,212.

${ }^{44}$ See end note 138 .
} 
southern South Australia Murray had more favourable experiences with the early Europeans than those elsewhere, such as Eyre Peninsula and the Coorong. ${ }^{95}$

The links that the Islanders had with mainland populations occasionally proved very useful to the colonial powers in eastern Australia. For instance, in 1831 after Captain Collet Barker failed to return from swimming across the Murray Mouth (Figure 6), his companions located the previously mentioned Aboriginal woman, Sally, at this time living among Aboriginal people at Cape Jervis. ${ }^{96}$ She had been recognised by one of the ship's crew as having been on a sealing vessel at King George Sound in Western Australia three years earlier. Sally could speak English 'tolerably well', and suggested to them that the Kangaroo Island sealers could help. ${ }^{97}$ Eventually, a party which included two seamen, Barker's servant, Sally and her 'uncle' Condoy, and the sealers Bates and Wallen, crossed to Cape Jervis in the sealers' whale boat. From here, they travelled over land to Lake Alexandrina, which Bates had already crossed on an earlier trip before Sturt had discovered it. ${ }^{98}$ They then constructed reed rafts in an Aboriginal manner, and travelled to the inside of the Murray Mouth where Barker had disappeared.

At the Murray Mouth, the cunning and experience of the Islanders was put to use. It is recorded that:

Here Bates formed a daring plan for obtaining some information on this subject [Barker's disappearance]. In the darkness of night he and his mates surprised a camp of natives. Bates acted the part of the orthodox ghost, dressed in a white sheet, and his costume and dismal groans so frightened the blackfellows that as soon as awake they fled in all directions. A young girl of about 16 bolted straight in Warley's [= Wallen's] arms, and he at once secured and gagged her. From her they learnt that Captain Barker had been speared by the natives and his body hidden in the scrub... The black girl was claimed by Warley as his property and lived with him at Hog Bay, assisting him to hunt. ${ }^{99}$

The fate of Barker was in this way discovered. Apparently after swimming the River Mouth, he had been tracked by three Aboriginal men. The latter had waited until they were certain Barker was unarmed, then killed him.

Although the reasons for the attack are not clear, it is possible that Barker was mistaken for a sealer from Kangaroo Island, and killed in reprisal for earlier overland raids by Islanders. The Aboriginal people in this part of the Lower Murray by this time clearly knew about Europeans. For instance, when Sturt travelled along the elbow of the River Murray at Goolwa towards the Mouth in 1830, he remarked that the local

\footnotetext{
${ }^{95}$ An account of the 'Maria' massacre on the Coorong is given by Penney in Register, 24 April 1841 and 26 June 1841 and by Pullen in Register, 15 August 1840. Also see Taplin 1859-1979, Journals, 1 December 1862; Davies 1881, pp.134,135; Bull 1884, pp.116-129; Hastings 1944 [1987, pp.84-90]; McCourt and Mincham 1987, p.136).

${ }^{96}$ Report by Dr Davis to the Colonial Secretary, 19th May 1831 [published 1921 in Proc. Roy. Geogr. Soc. Aust. S. Aust. Br., vol.22, pp.19-29]. Report cited by Moore 1924, pp.100,101). ${ }^{97}$ Report by Dr Davis 1831 [1921, p.24]).

${ }^{98} \mathrm{Gill}(1906)$ claims that the sealer Bates had discovered Lake Alexandrina before Sturt. See Mayo 1937, p.76).

${ }^{94}$ Advertiser, 27 December 1886.
} 


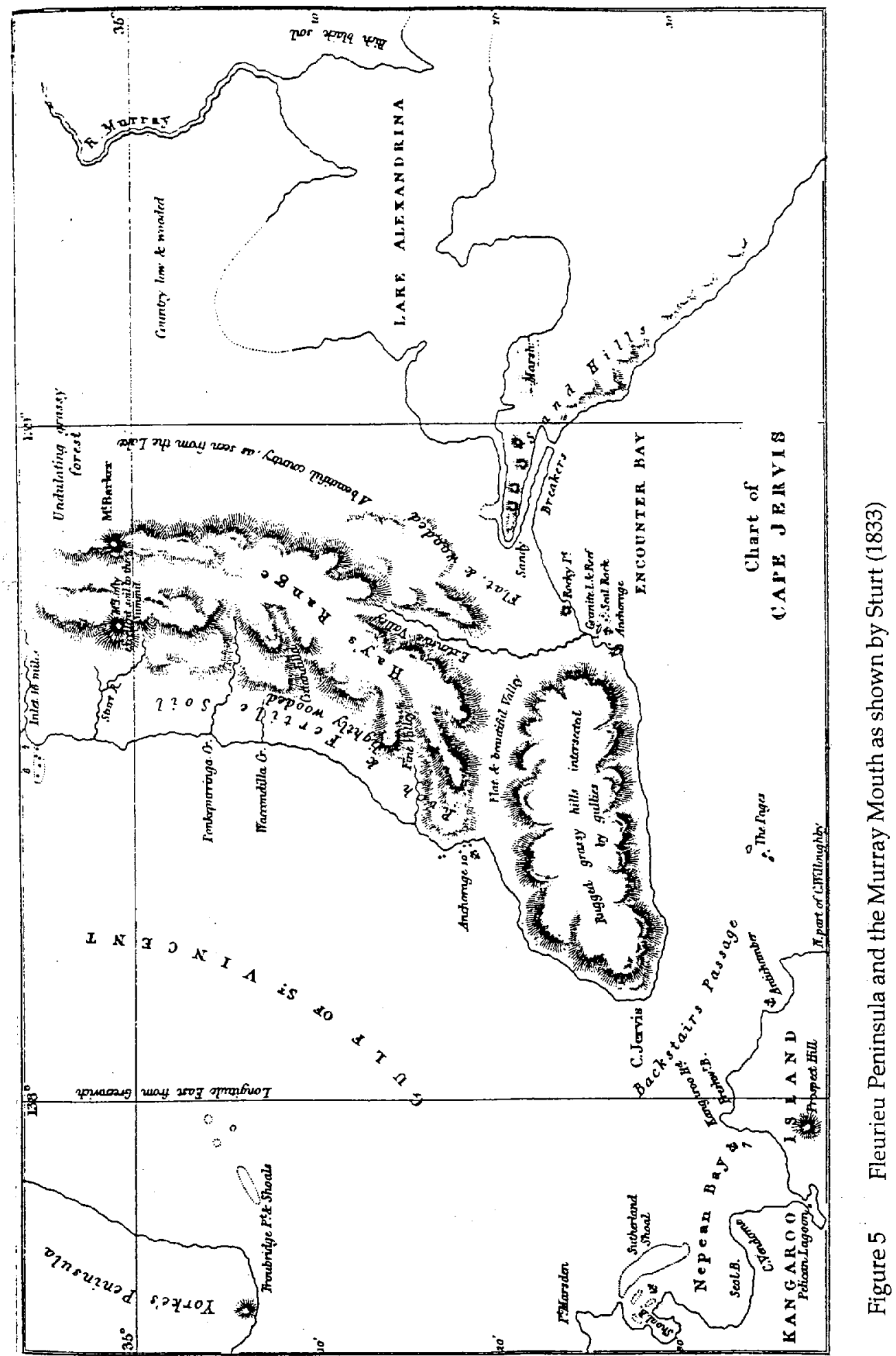




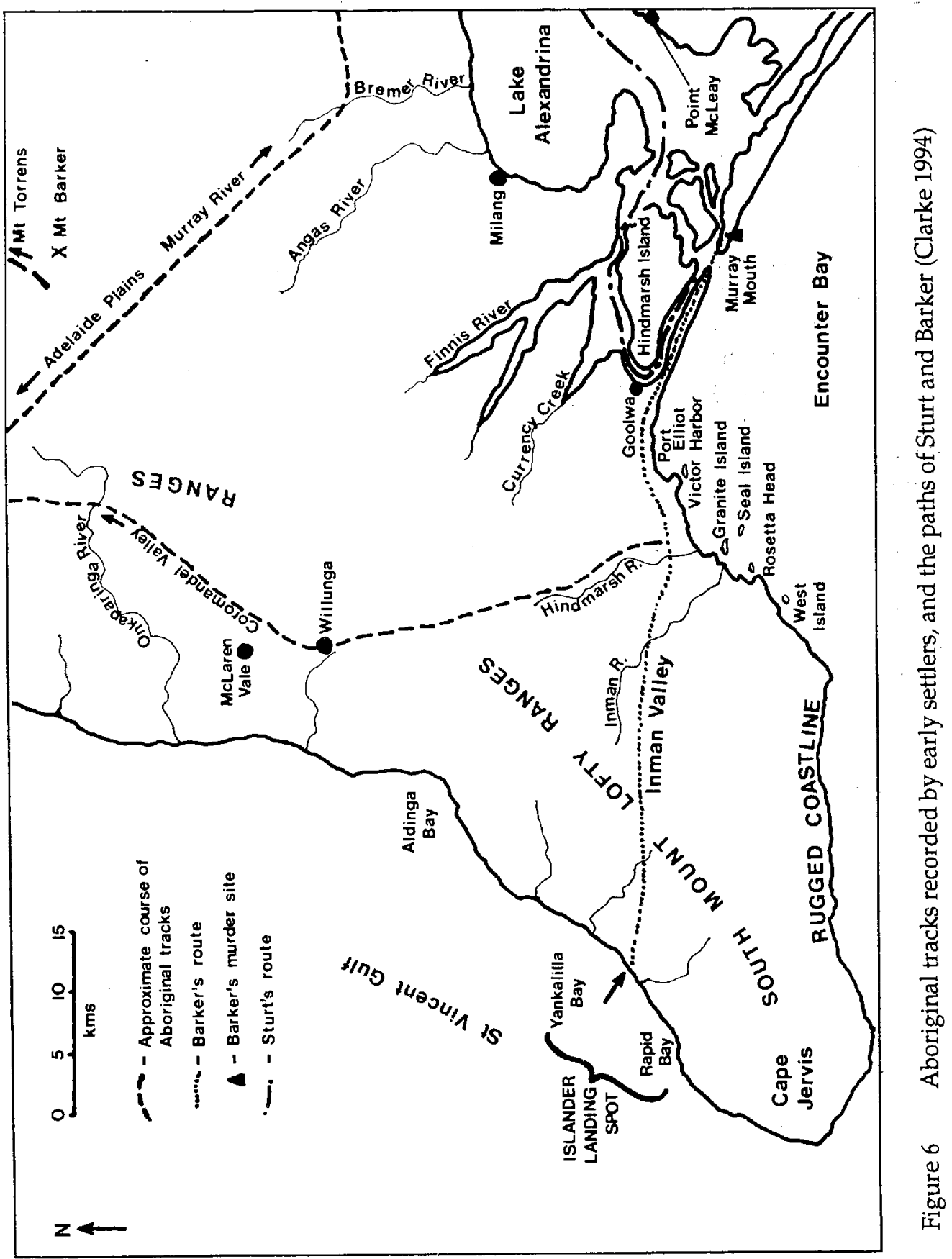


Aboriginal people were 'perfectly aware of the weapon [gun] I carried, for the moment they saw it, they dashed out of their hiding place'. ${ }^{100}$ It is possible that wife stealing had created disutes between the Islanders and the Aboriginal people living near the Murray Mouth. ${ }^{101}$ Nevertheless, without the assistance of the Islanders and their Aboriginal companions, it is doubtful whether the circumstances of Barker's disappearance would ever have become known. ${ }^{102}$ Bates and Wallen received payment for their services in obtaining information.

In spite of the dangerous exploits of the Islanders, their life on Kangaroo Island was generally 'luxurious and lazy' with Aboriginal people doing the bulk of the work. ${ }^{94}$ A large dwelling built at Antechamber Bay was the Islander's main depot. A considerable fluctuation in Kangaroo Island population levels is evident in the scant records of the pre-colonial period. In 1831, Robinson listed the names of thirteen Aboriginal women he knew to be living with sealers on the island. ${ }^{105}$ In 1833, Captain Jones claimed that there were seven Englishmen living on the island, with five Aboriginal women. ${ }^{106}$ In 1836, when the colonists reached Kangaroo Island, a settler thought there were six sealers on the island with a number of wives. ${ }^{107}$ In apparent conflict with this, an additional report at the time claimed that there were eight European men and sixteen Aboriginal women living on Kangaroo Island. ${ }^{108}$ Another settler from 1836 said that the average number of wives each sealer had was three. ${ }^{109}$ Here, one man reportedly had three wives and no children, another had the same number of wives and twenty children. An exact account of all the Aboriginal people taken to Kangaroo Island will never be possible, as there are no detailed records of arrivals, departures, births or deaths before 1836.

\section{The use of Aboriginal skills by official colonists}

The first of the five ships bringing British colonists to South Australia reached Kangaroo Island on 27 July 1836; the colonists were surprised at the harshness of the new landscape. Upon landing, the settlers were helped by the Islanders to locate drinking

\footnotetext{
${ }^{100}$ Sturt 1833, vol.2, p.166).

"where was clearly tension between the Islanders and particular Aboriginal groups due to wife stealing. For instance, the Kangaroo Island sealer, Nat Thomas, had expressed fear in meeting the mainland relatives of one of his wives (Bull, 1884, p.32).

${ }^{102}$ Hahn (1838-1839 [1964, p.132]) provides a different account, claiming that Aboriginal people killed Barker for the shining compass which he had tied to his head. He states that had Barker given the Aboriginal people the compass, he would not have been killed.

${ }^{103}$ Advertiser, 27 December 1886.

${ }^{104}$ Ibid.

${ }^{105}$ Robinson cited in Cumpston, 1970, p.171).

${ }^{10} \mathrm{~J}$. Jones 1835 [1921, p.75]). The names of the white men he listed were Walley [= Wallen], Nathanial Thomas, James Allen, William Day and William Walker. There were two men he did not name.

${ }^{107}$ Morphett cited in Cumpston, 1970, p.126).

${ }^{110}$ Hart cited in Cumpston, 1970, p.127). Hart lists the Europeans as Nathanial Thomas and George Bates living at Antechamber Bay; William Day, James, Henry. Walley (Wallen) and a young Englishman at Pelican Lagoon; and William Cooper and Peter Johnson at Nepean Bay.

${ }^{104}$ Observer, 15 January 1898.
} 
water to replenish their supplies, ${ }^{110}$ and were sold or bartered wallaby skins and meat that had been caught by Islander women. 111 On 21 August 1836, Colonel Light arrived at Kangaroo Island from England on the Rapid. Light gained geographic information concerning the location of bays on the mainland from the Islanders. ${ }^{\mathrm{1}}{ }^{2}$ The Islanders also described to the settlers the climate of the region. ${ }^{113}$ They informed Light of the mistake in attempting to settle on Kangaroo Island, suggesting that land to the north of Cape Jervis would be more suitable than either the island or Encounter Bay.

The relatively open 'grasslands' on the eastern side of Saint Vincent Gulf, north from Cape Jervis, impressed many of the colonists, particularly when it was compared with the dense brush of Kangaroo Island. ${ }^{114}$ For instance, it was said that at this time the Rapid Bay district on the mainland 'everywhere resembled a gentleman's parkgrass growing in the greatest luxuriance, the most beautiful flowers in abundance... 115 It is ironic that the distinction between the two landscapes was largely due to firing practices of the Aboriginal inhabitants. While the mainland was well populated, the island lay beyond the reach of Aboriginal hunters and gatherers. Therefore, the landscape created by Aboriginal people in the pre-European period had an unintended effect of directing settlement towards the eastern Saint Vincent Gulf region. ${ }^{116}$

The settlers who arrived on Kangaroo Island in 1836 employed the Islander Bates to do some hut building in their holdings there. ${ }^{117}$ Light hired other Islanders, William Cooper and his two wives-Doughboy and Sall, to go with his surveying party to Rapid Bay. ${ }^{118}$ Aboriginal people travelled overland from Encounter Bay with Cooper to meet Light's party. The Island women, who had 'kangaroo dogs' from the island, were able to supply Light's men with fresh meat which they cooked for them. Light reportedly had good relations with the Aboriginal people of the Rapid Bay 'band'. 119 They carried wood for him, brought reeds for thatching and otherwise rendered Light such help as they could. The Aboriginal people slept around his hut at night. When Light in the Rapid was trying to find a good harbour, for which he had an account from the sealer John Jones, an Aboriginal woman from Kangaroo Island on board showed him the mouth of the Onkaparinga River. ${ }^{120}$ Light's men added to their provisions by buying potatoes from a sealing vessel that was passing through. ${ }^{121}$ The established network that the Islanders had with the mainland Aboriginal groups and passing merchant vessels thus

\footnotetext{
${ }^{110}$ Advertiser, 27 December 1886. Morphett (1836, p.7) states that the sealers and some Aboriginal people had shown the colonists of 1836 a reliable supply of drinking water at Pat Bungar, a small valley a few kilometres north of Cape Jervis.

"Southern Australian, 27 September 1844. Also see Nunn 1989, p.58).

${ }^{113}$ Advertiser, 27 December 1886.

${ }^{113}$ Morphett 1836, p.13).

${ }^{114}$ Gouger 1838, pp.22-29; Morphett cited in Scott, 1839, pp.11,12; Mitchell cited in Scott, 1839 , p.15; Dutton 1960, pp.170,172-175).

${ }^{115}$ Thomas 1925, p.47).

${ }^{116}$ Clarke 1991, pp.59,60).

${ }^{117}$ Observer, 15 January 1898.

${ }^{118}$ Dutton 1960, p.172). The identity of his two wives at this time is given elsewhere (Advertiser, 27 December 1886).

${ }^{119}$ Gouger 1838, pp.46,47).

${ }^{120}$ See Jones 1835 [1921]; Dutton 1960, pp.175-180).

${ }^{121}$ Price 1924, p.56).
} 
proved useful to the official colonists of 1836 who had arrived needing directions, fresh food, drinking water, and physical assistance.

During the establishment phase of the Colony of South Australia, the authorities took advantage of the knowledge Kangaroo Islanders had of the southern Aboriginal inhabitants. Cooper and his wives were moved to Encounter Bay in the Lower Murray to develop relations between the new colonists and the Aboriginal people. ${ }^{122}$ They were also engaged in the creation of a garden there. ${ }^{123}$ Light employed Cooper and his wives as interpreters and as 'go-betweens' for the colonists and the Aboriginal groups. ${ }^{124}$ In early 1837, Nat Thomas, a sealer from Kangaroo Island, helped colonists track two missing horses south from Adelaide. ${ }^{125}$ Thomas already knew the area through his sealing activities and was able to point out 'native wells' under the sandhills near the mouth of the Onkaparinga River. On one occasion, the party was surrounded by Aboriginal people whom Thomas recognised as Onkaparinga and Encounter Bay people. Although Thomas knew a few of their words, he kept out of sight. The woman he had on Kangaroo Island was from their community and they were reportedly not pleased at her absence. In the colonists' camp at Glenelg near Adelaide, an Aboriginal woman regularly supplied the newcomers with a type of water cress for food. ${ }^{126}$ The Europeans reportedly had no knowledge of where it was obtained. Some of the Aboriginal helpers later moved from Glenelg to Adelaide, where they were employed in jobs such as fetching water from the river. ${ }^{127}$ The Islanders and local Aboriginal people were valuable as guides and labourers for the coastal regions from Adelaide to the Lower Murray region.

At the time of colonisation, the need for interpreters at Adelaide and Encounter Bay was lessened because many of the Aboriginal people there already spoke English, having learnt it from the Islanders. ${ }^{128}$ The area covered by this region was considered by the official colonists to have an Aboriginal population more amenable to European settlement than both Eyre and Yorke Peninsulas. ${ }^{129}$ Therefore, not only did Aboriginal people assist the European colonists, but the nature of European relations with the various Aboriginal groups was one of several factors influencing the placing of the site of the capital.

The European colonists of 1836 set up a new iconography of the landscape by naming topographic features after the English aristocracy, and significant explorers and settlers. However, there are also many examples of place names that pre-date the 1836

\footnotetext{
${ }^{122}$ Light 1839, p.5). See other accounts: Dutton 1960, p.174; Cumpston 1970, p.146). On the point of the identity of the sealer actually employed by Light, Cumpston has confused George Bates for William Cooper.

${ }^{123}$ The Aboriginal wives of the Islanders were probably some of several Tasmanian people reported to be living among settlers at Encounter Bay by the early 1840s (Penney [as 'Cuique'] in S. Aust. Mag., September 1842, vol.2, pp.18-23).

${ }^{124}$ Advertiser, 27 December 1886. Cooper's wife, Sall, is known to have been Tasmanian.

${ }^{125}$ Bull 1884, pp.32-36).

${ }^{126}$ Thomas 1925, p.69).

${ }^{127}$ Thomas 1925, p.71).

${ }^{128}$ Penney in Register, 21 November 1840.

${ }^{124}$ Light (1839, p.21) stated that the Adelaide Plains site was good for settlement as the 'natives more friendly than at Port Lincoln and Yorke Peninsula'. This was also supported by the views of the Islanders (see end note 45 ).
} 
settlement. For example, John Morphett's account in 1836 of the Colony of South Australia uses names gained from sealers and Aboriginal people, such as 'Pat Bungar' for a small valley just north of Cape Jervis, 'Yanky Lilly' (= Yankalilla) and 'Aldinghi Plains' (= Aldinga). ${ }^{130}$ Here, the role of the sealers in naming parts of the landscape was acknowledged by Morphett. The sealers had gained these place names from their Aboriginal contacts. The place names used by Sturt also appear to have been influenced by the sealers. In Sturt's map of the Fleurieu Peninsula and the Lower Murray, there are place names, some of them Aboriginal, for localities he did not visit (Fig.3). It has been suggested that some of these topographical features, such as Granite Island and Seal Rock, were given their names by sealers sometime before $1830 .{ }^{131}$ Nevertheless, as with most names derived from European and other sources, the etymological sense of the Aboriginal place names are generally not known by the broader public. Linguistic studies in many instances have established their original meanings.

In the case of the place names of Kangaroo Island, today there are a number of names in official use that derive from the French explorer Baudin, such as D'Estrees Bay and Cape du Couedic. ${ }^{133}$ The present use is presumably the result of the publication of Baudin's expedition reports. The American whalers have also left their mark on Kangaroo Island, as the term Pelican Lagoon given by Flinders was replaced by the name of American River, because of Pendleton's activities there as described above. ${ }^{134}$ There have been, and are presently, many examples of place names on the island put into use by the pre-1836 sealers, such as Hog Bay, Harvey's Return and Murrell's Landing. Interestingly, there are no Aboriginal place names on Kangaroo Island recorded from the early period of sealing and whaling, in spite of the Tasmanian and mainland-derived poptalations of Aboriginal people living there.

The early recognition by Europeans of the relationship that Aboriginal people had developed with Kangaroo Island is evident in their use of Aboriginal trackers. For instance, in 1836 when the colonist Joseph Finch disappeared in the Rapid Bay district, the Islander Cooper and some Aboriginal people searched for him. ${ }^{135}$ In the same year, the Islander Wallen and his two wives, Puss and Polecat, set out with a party on Kangaroo Island to find two missing passengers of the Africaine who had attempted to cross on foot from the western side. ${ }^{36}$ Here the role of the Aboriginal women was described as being 'trackers'. Aboriginal trackers were routinely employed to search for lost stock in southern South Australia. ${ }^{137}$

The role of tracker and Aboriginal interpreter often merged. In 1840, Aboriginal guides from the Encounter Bay area were used by colonial authorities in their expeditions to discover the whereabouts of the survivors of the Maria wreck. In the

\footnotetext{
${ }^{131}$ Morphett 1836, pp.6-9).

${ }^{131}$ Cameron 1979, p.2).

${ }^{132}$ A linguistic study is the 'Aboriginal Place Name Index' compiled by N.B. Tindale, Anthropology Archives, S.A. Museum.

${ }^{133}$ Cockburn 1908 [1984, pp.52,60]).

${ }^{134}$ The American style spelling of Victor Harbor is possibly another early American influence Sutton, 1989).

${ }^{135}$ Advertiser, 27 December 1886.

${ }^{136}$ Observer, 20 May 1899. See also Thomas 1925, pp.43-46).

${ }^{137}$ Wilkinson 1848, pp.319,320).
} 
investigation of the subsequent massacre of the Maria shipwreck survivors on the Coorong, three Aboriginal men-'Encounter Bay Bob', 'One-arm Charley' and 'Peter', were part of the investigating crew. ${ }^{138}$ It is interesting to note that all three appear to have had experience in whaling and sealing, due to their early connections with Kangaroo Island. ${ }^{139}$ During the early days of European settlement at Encounter Bay, 'native guides' were routinely used by the police.

In 1844, Inspector Alexander Tolmer was sent to Kangaroo Island to arrest escaped bushrangers who were living in the bush on the island. These outlaws were living there with the assistance of two Aboriginal women, Sal and Suke. ${ }^{141}$ Tolmer was well aware that those he was to pursue had a geographical edge over him. For this reason, Tolmer hired two other Aboriginal women on the island, Bet and Old Waub, as trackers. ${ }^{142}$ In addition, one of the men accompanying Tolmer was a policeman stationed at Willunga, who was known to have formerly served as a whaler with Captain Hart before official settlement. Tolmer considered that the knowledge of the Kangaroo Island area this man possessed would be particularly useful. Tolmer's party successfully tracked the escapees, and he claimed that he would have failed to find them without the help of the Aboriginal women. As with the earlier search for Barker, the Islanders here received payment for the tracking services of their wives. ${ }^{143}$

Knowledge of Kangaroo Island gained by Aboriginal women's hunting and gathering expeditions proved useful on many occasions. In November 1853, the steamer, Osmanli, struck a reef near Cape Linois in $\mathrm{D}^{\prime}$ Estree Bay. ${ }^{144}$ A rescue party that included the Islander Nat Thomas and an Aboriginal woman, reached the stranded passengers by travelling overland. The location of a soak to provide drinking water was shown by the Aboriginal woman, probably the wife or daughter of Nat Thomas. In December 1855, the Islander Buik and an Aboriginal woman searched for a missing man named Pennington who had disappeared in thick scrub on Kangaroo Island near Osmanli Beach. ${ }^{45}$ Troopers from Adelaide, Coward and Dundas, were dispatched in January 1856 to help find Pennington, but even with Aboriginal guides, were unsuccessful. The Aboriginal residents of the island would have had extensive geographic knowledge of the barren south coast of the island, through the hunting and gathering expeditions of the women.

The exploitation of Kangaroo Island's mineral resources was on occasion facilitated by the earlier Aboriginal residents. For instance, during Tolmer's raid on the island, Old Bet (or Betsey) had told him about the abundance of pitch there. ${ }^{146}$ This led to an

\footnotetext{
${ }^{134}$ There were three expeditions with which these three Aboriginal men, trained in whaling and sealing, were a part. For an account of Pullen's expedition, see Register, 15 August 1840. For Penney's expedition, see Register, 24 April 1841. Also see Lendon 1930, p.23). Bull (1884, pp.116-129) gives an account of O'Halloran's expedition.

${ }^{134}$ Encounter Bay Bob served as a guide and tracker on Sturt's expedition from Adelaide to the North West Bend of the Murray River in 1839 (Davies, 1881, pp.121-168).

${ }^{141}$ Bull 1884, pp.58,59).

${ }^{141}$ Tolmer 1882, vol.1, pp.306-323; vol.2, pp.1-11).

${ }^{142}$ Bet and Wauber (= Old Waub) were possibly both Tasmanian (Clarke, 1997).

${ }^{143}$ Cumpston 1970, p.176).

${ }^{144}$ Nunn 1989, pp.95-97).

${ }^{145}$ Cockburn 1908 [1984, p.172]).

${ }^{14 k}$ Tolmer 1882, vol.1, pp.320,321).
} 
attempt by Tolmer, Nat Thomas and Mrs Seymour (daughter of Thomas and Old Bet) to lodge a claim on Kangaroo Island for natural pitch. In 1856, Old Bet lodged a gold claim for the Cape Willoughby Ranges with the Gold Research Committee. ${ }^{149}$ She stated that after some Islanders had returned from the mainland gold fields, she had been shown gold nuggets they had. She had exclaimed 'Me see him plenty like it that yellowfellow tone.' She explained that when her son, Nat, was very young, she and another Aboriginal woman had collected a number of nuggets and had beaten them out or 'made them long' as she had put it. However, Aboriginal knowledge of the island was not always taken without question. William A. Cawthorne, the son of the first lighthouse keeper at Cape Willoughby, claimed that Old Bet was not to be taken seriously. ${ }^{148} \mathrm{He}$ considered that island rumours of gold were based on Tolmer's accidental discovery of it while capturing bushrangers in 1844. Cawthorne considered that Tolmer's find was in a different area from where Betsey had lodged her claim. Cawthorne had already lodged a claim to the Gold Research Committee for his suggested area of the island.

Some of the Aboriginal inhabitants on Kangaroo Island were returned to their place of origin after 1836. Although a few Tasmanian women were eventually taken back to Tasmania, several of them chose not to return to their previous homeland. ${ }^{149}$ This was perhaps because of their knowledge of events in Tasmania. For instance, by 1830 only three hundred fully descended Tasmanians of an original population of several thousand remained. ${ }^{150}$ It is possible that some Tasmanians were absorbed into the mainland Aboriginal population, while others remained on Kangaroo Island. ${ }^{15 \mathrm{t}}$ In 1844, there were twelve Aboriginal women living on Kangaroo Island, several of whom were originally from Tasmania. ${ }^{152}$ They were judged to be between forty and fifty years of age, having been on the island upwards of seventeen years. In the 1860s, one Aboriginal family of mainland ancestry was moved from the island to the Point McLeay Mission in the Lower Murray. ${ }^{153}$ By the 1870 s, it seems that most of the Aboriginal people who had originally been taken to Kangaroo Island, had either died or were removed. The exceptions were three Tasmanian women, all of whom outlived the so-

\footnotetext{
${ }^{147}$ Register, 13 September 1856 (reprinted Observer, Supplement, 13 October 1906).

${ }^{148}$ Register, 15 September 1856 (reprinted Observer, 20 October 1906). W.A. Cawthorne was an early Adelaide painter and ethnographer (1844).

${ }^{149}$ Thomas Willson, Observer, 7 October 1871.

${ }^{1510}$ Jones 1974, p.319).

${ }^{151}$ Wood Jones (1934) claims that some Tasmanians may have drifted into mainland populations after European colonisation. Mollison (1976, Appendix) suggests that at least one present day Aboriginal family in the Lower Murray has Tasmanian descent. My fieldwork has shown that for the family mentioned by Mollison, this is very likely. Furthermore, among contemporary Aboriginal people, there is knowledge of additional genealogical links between Ngarrindjeri and Tasmanian groups.

${ }_{i 52}$ Tolmer in the Observer, 28 September 1844.

${ }^{153}$ In 1860, Taplin records that an Aboriginal woman and her children were sent by the Government from Kangaroo Island to the Point McLeay Mission (1859-1879, Journals, 22 December 1860). The woman's name was Nellie Raminyemmermin, the widow of John Wilkins, who was a Russian Finnish whaler living on Kangaroo Island (Kartinyeri, 1990, vol.1, p.13).
} 
called 'last of the Tasmanians', Truganina. ${ }^{154}$ The last of these island women died sometime around 1888 . $^{155}$

The early Islanders did leave descendants among later Kangaroo Island populations. With the anthropological interest in the 'extinct races', one woman, who had been the child of a white sealer and a Tasmanian woman, was the subject of special anatomical studies. ${ }^{156}$ However, the Aboriginal people on Kangaroo Island became socially cut off from other former sealing stations in the Bass Strait after official settlement. ${ }^{157}$ With the large influx of farmers on Kangaroo Island, its distinctive Aboriginality has largely remained in the past. ${ }^{158}$ In contrast, the descendants of the sealers and their Aboriginal wives in the Furneaux Group of Tasmania have formed a culturally distinctive population that persists today. ${ }^{159}$ Nevertheless, there are still people living on Kangaroo Island who can trace descent to a Tasmanian woman brought there sometime before $1836 .{ }^{160}$

\section{Conclusion}

From the evidence put forth here, it is clear that both the early sealer/whalers and their Aboriginal contacts did have special roles in the initial formation of the Colony of South Australia. One of the main problems that official colonists faced upon their arrival in 1836 was essentially lack of geographical knowledge. Initially through the medium of the sealers, Aboriginal people helped the colonists in a variety of ways that drew upon their pre-European knowledge of the landscape. The historical reconstruction of the interaction between sealers, Aboriginal people and the official colonists, is therefore not simply of antiquarian interest, but provides deeper understanding of European and Aboriginal settlement patterns since 1800 .

Published accounts of the formation of the Colony of South Australia have tended to focus on official events and people. The merchants and sealers operating in southern Australian waters during the early period are barely mentioned in most Australian history texts. The general histories of South Australia, such as that provided by Blacket, Price and Dutton, note the existence of the early sealers solely because they were the first Europeans there. British history has given prominence to explorers and founders of colonies, rather than to sealers and whalers who were not part of government-run expeditions. The treatment of the Aboriginal inhabitants has also largely been confined to contextual material, to reinforce the 'wilderness' quality and 'primitiveness' of the Australian landscape. The pre-1836 populations of both European and Aboriginal

\footnotetext{
${ }^{154}$ Kangaroo Island resident, Thomas Willson, claimed in 1871 that there were three Tasmanian women left there, the rest having been taken back to Tasmania many years earlier by Captain Duff and others (Observer, 7 October 1871). Duff was captain of the Africaine in 1836-1837 (Dutton, 1960, pp.183,186,187,211). One of the last three Tasmanian women on the island was possibly Truganina's sister (Clarke, 1997). Note that Truganina (= Trugananna, Truganini) was also known as Lalla Roohk.

${ }^{155}$ Tindale $1937 \mathrm{a}$, p.32).

${ }^{356}$ Basedow 1914; Berry 1907).

${ }^{157}$ Ryan 1981, p.222).

${ }^{158}$ See Nunn (1989) for a history of Kangaroo Island.

${ }^{i 59}$ Malcolm 1920; Tindale 1953; Mollison 1974, 1976; Mollison and Everitt 1976).

${ }^{160}$ Tindale 1937a, p.32; Mollison 1976, Appendix; Clarke (1997) provide genealogical data of families with Tasmanian descent living on Kangaroo Island and in the Lower Murray region.
} 
people have generally not been considered significant in the development of the Colony of South Australia.

During the exploration phase of Aboriginal and European relations in southern South Australia, there was an equal relationship between the colonists and the indigenous populations, albeit sometimes brutal. However, gradually their relations became more asymmetrical as the technology and culture gap between them grew. As land was developed for agriculture and the social structure of the official colony was established, the reliance by Europeans upon Aboriginal knowledge of the environment became less and less. In contrast to the early sealers, the official settlers of South Australia quickly become independent of the Aboriginal source of landscape knowledge. This is not to say that Europeans did not use Aboriginal labour in agriculturally-based industries, simply that the hunter-gatherer knowledge described above was no longer being utilised. Nevertheless, we can not understand European colonisation of southern South Australia without fully considering the relationship of early Europeans and the Aboriginal inhabitants.

\section{Acknowledgments}

This paper formed part of a chapter of a PhD thesis in cultural geography and social anthropology. It was read out at the Anthropological Society of South Australia in 1992. Drafts of this work were commented upon by Chris Anderson, Peter Smailes, Kingsley Garbett, and Rob Amery. Andrew Hughes photographed the display panel of Aboriginal artefacts.

Philip Clarke is Senior Curator of Aboriginal Collections and Coordinator of the Anthropology Department at the South Australian Museum. His doctoral dissertation in social anthropology and cultural geography focussed on the Aboriginal culture of the Lower Murray region of South Australia.

\section{References}

Baker, R. 1989. 'Land is Life: Continuity Through Change for the Yanyuwa from the Northern Territory of Australia.' Ph. D. thesis. University of Adelaide, Adelaide.

Barwick, D.E. 1985. This most resolute lady: a biographical puzzle. In Barwick, D.E., Beckett, J. and Reay, M. (eds) Metaphors of Interpretation: Essays in Honour of W.E.H. Stanner. Australian National University Press, Canberra.

Basedow, H. 1914. Relic of the lost Tasmanian race-obituary notice of Mary Seymour. Man, pp.161,162.

Berry, R.J.A. 1907. A living descendant of an extinct (Tasmanian) race. Proc. R. Soc. Vic., vol.20, pp.1-20.

Blacket, J. 1911. History of South Australia. Hussey \& Gillingham, Adelaide.

Blainey, G. 1977. The Tyranny of Distance: How Distance Shaped Australia's History. Macmillan, Sydney.

Blakers, M., Davies, S.J.J.F. and Reilly, P.N. 1984. The Atlas of Australian Birds. Royal Australasian Ornithologist Union. Melbourne University Press, Melbourne.

Bull, J.W. 1884. Early Experiences of Life in South Australia and an Extended Colonial History. E.S. Wiggs \& Son, Adelaide. 
Cameron, J. 1979. Yilki-A Place by the Sea. Yilki Uniting Church, Victor Harbor.

Cawthorne, W.A. 1854 [1926]. The Kangaroo Islanders: a Story of South Australia Before Colonisation 1823. Rigby, Adelaide.

Clarke, P.A. 1991. Adelaide as an Aboriginal Landscape. Abor. Hist., vol.15, pt 1, pp.5472 .

Clarke, P.A. 1994. Contact, conflict, and regeneration: Aboriginal Cultural Geography of the Lower Murray, South Australia. Ph.D. thesis. University of Adelaide, Adelaide.

Clarke, P.A. 1997. The Aboriginal presence on Kangaroo Island, South Australia. In Simpson, J. and L. Hercus (eds) Aboriginal Portraits of $19^{\text {th }}$ Century South Australia. Aboriginal History Monograph. In press.

Cockburn, R. 1984. What's in a Name? Nomenclature of South Australia. Revised edition. Ferguson, Adelaide.

Cooper, H.M. 1952. French Exploration in South Australia. Published by the author, Adelaide.

Cooper, H.M. 1954. Kangaroo Island's wild pigs: Their possible origin. S. Aust. Nat., vol:28, pt 5, pp.57-61.

Cumpston, J.S. 1970. Kangaroo Island 1800-1836. Roebuck Society Publication no.1. Roebuck, Canberra.

Davies, E. 1881. The Story of an Earnest Life. A Woman's Adventures in Australia, and in Two Voyages Around the World. Central Book Concern, Cincinnati.

Draper, N. 1988. Stone tools and cultural landscapes: investigating the archaeology of Kangaroo Island. Proc. R. Geogr. Soc. Aust. S. Aust. Br., vol.88, pp.15-36.

Dutton, G. 1960. Founder of a City: the Life of Colonel William Light ... Cheshire, Melbourne.

Ellis, R.W. 1976. The Aboriginal inhabitants and their environment. In Twidale, C.R., Tyler, M.J., and Webb, B.P. (eds) Natural History of the Adelaide Region. Royal Society of South Australia, Adelaide.

Finney, C.M. 1984. To Sail Beyond the Sunset: Natural History of Australia 1699-1892. Rigby, Adelaide.

Finnis, H.J. (n.d.) Early Settlers on Islands in Bass Straits. Pioneers Association of South Australia, Adelaide.

Flinders, M. 1814. Voyage to Terra Australis. Facsimile edition. State Library of South Australia, Adelaide.

Foster, R. 1983. 'The Bunganditj: European Invasion and the Economic Basis of Social Collapse.' M. A. thesis. University of Adelaide, Adelaide.

Gibbs, R.M. 1969. A History of South Australia. Balara Books, Adelaide.

Gill, T. 1906. Who discovered Lake Alexandrina? Proc. R. Geogr. Soc. Aust. S. Aust. Br., vol.8, pp.48-54.

Gill, T. 1909. A cruise in the S.S. 'Governor Musgrave'. Proc. R. Geogr. Soc. Aust. S. Aust. Br., vol.10, pp.90-184.

Gouger, R. 1838. South Australia in 1837. Harvey \& Darton, London.

Hahn, D.M. 1838-1839. Extracts from the 'Reminiscences of Captain Dirk Meinertz Hahn, 1838-1839.' Translated by Blaess, F.J.H. and L.A. Triebel 1964. South Australiana, vol.3, no.2, pp.97-134. 
Harvey, A. 1941. Flint implements of Tasmanian manufacture found at Cape Hart, Kangaroo Island. Rec. S. Aust. Mus., vol.6, no.4, pp.363-368.

Hastings, J.G. 1944. Tragedies of the Coorong. In McCourt and Mincham (1987) The Coorong and Lakes of the Lower Murray. National Trust, Beachport.

Hiatt (Meehan), B. 1967-1968. The food quest and economy of the Tasmanian Aborigines. Oceania, vol.38, pt 2, pp.99-133 and pt 3, pp.190-219.

Hosking, W.J. 1973. 'Whaling in South Australia, 1837-1872.' Honours Thesis. Flinders University, Adelaide.

Jones, J. 1835 [1921]. Port Adelaide River. Proc. R. Geogr. Soc. Aust. S.Aust. Br., vol.22, pp.73-75.

Jones, R. 1974. Tasmanian Tribes. An appendix to Tindale, N.B. Aboriginal Tribes of Australia. Australian National University Press, Canberra.

Kartinyeri, D. 1990. The Wilson Family Genealogies. 2 vols. South Australian Museum, Adelaide.

Kingscote Country Women's Association n.d. Kangaroo Island. Past and Present. Being a Short History of the Oldest Settlement in South Australia. Kingscote Country Women's Association, Kingscote.

Kostoglou, P. and McCarthy, J. 1991. Whaling and Sealing Sites in South Australia. Australian Institute for Maritime Archaeology Special Publication no.6.

Kuhn, W. and Fowler, W. 1886. Yorke's Peninsula, South Australia. In Curr, E.M. (ed) 1886-7. The Australian Race. Trubner, London.

Lampert, R.J. 1979. Aborigines. In Tyler, M.J., Twidale, C.R. and J.K. Ling (eds) Natural History of Kangaroo Island. Royal Society of South Australia, Adelaide.

Leigh, W.H. 1839. Reconnoitring Voyages and Travels With Adventures in the New Colonies of South Australia. Smith, Elder \& Co., London.

Lendon, A.A. 1930. Dr Richard Penney (1840-1844). Proc. R. Geogr. Soc. Aust. S. Aust. Br., vol.31, pp.20-32.

Light, W. 1839. A Brief Journal. Adelaide.

McCourt, T. and H. Mincham (eds). 1977. Two Notable South Australians: Cpt. Emmanuel Underwood 1806-1888 and Duncan Stewart 1834-1913. Beachport Branch of the National Trust, Beachport.

McCourt, T. and Mincham, H. 1987. The Coorong and Lakes of the Lower Murray. National Trust, Beachport.

MacKenzie, J.M. 1976. Sealing, Sailing and Settling in South-western Victoria. Lowden, Melbourne.

Malcolm, L.W.G. 1920. Short notes on the inhabitants of Cape Barren Island, Bass Strait, Tasmania. Man, no.71, pp.145-149.

Mayo, M.P. 1937. The Life and Letters of Colonel William Light. F.W. Preece \& Sons, Adelaide.

Mollison, B.C. 1974. A Synopsis of Data on Tasmanian Aborigines. Second edition. Vol.1.' University of Tasmania, Hobart.

Mollison, B.C. 1976. The Tasmanian Aborigines: Tasmanian Aboriginal Genealogies, with an Appendix on Kangaroo Is. Vol.3, Part 1. University of Tasmania, Hobart. 
Mollisøn, B.C. and C. Everitt 1976. A Chronology of Events Affecting Tasmanian Aborigines (1772-1976). Vol.2. University of Tasmania, Hobart.

Moore, H.P. 1924. Notes on the early settlers in South Australia prior to 1836. Proc. $R$. Geogr. Soc. Aust. S. Aust. Br., vol.25, pp.81-135.

Morphett, J. 1836. Latest Information from the Colony. John Gliddon, London.

Newland, S. 1921. Reminiscences of pioneer life. Proc. R. Geogr. Soc. Aust. S. Aust. Br., vol.20, pp.89-110.

Nunn, J.M. 1989. This Southern Land: a Social History of Kangaroo Island 1800-1890. Investigator Press, Adelaide.

Osterstock, A. 1975. The Story of Kangaroo Island. The author, Adelaide.

Peron, F. 1816 [1979]. Historical Perspective: Kangaroo Island-1803. In Tyler, M.J., Twidale, C.R. and J.K. Ling (eds) Natural History of Kangaroo Island. Royal Society of South Australia, Adelaide. Translated into English from 'Voyage de Decouvertes aux Terres Australes', vol.2, chapter 24.

Plomley, B. and K.A. Henley 1990. 'The Sealers of Bass Strait and the Cape Barren Island Community.' Blubber Head Press, Hobart. An offprint of the Tas. Hist. Res. Assoc. Pap. Proc., 1990, vol.37, nos.2-3.

Price, A.G. 1924. The Foundation and Settlement of South Australia 1829-1845. Preece, Adelaide.

Reudiger, W.J. 1980. Border's Land-Kangaroo Island 1802-1836. Adelaide.

Reynolds, H. 1990. With the White People. Penguin, Melbourne.

Ryan, L. 1981. The Aboriginal Tasmanians. University of Queensland Press, St Lucia.

Scott, T. 1839. Description of South Australia... Duncan Campbell, Glasgow.

Slater, P. 1978. Rare and Vanishing Australian Birds. Rigby, Adelaide.

Starbuck, A. 1878. History of the American Whale Fishery. 2 Vols. Reprinted in 1964 by Argosy-Antiquarian, New York.

Strahan, R. (ed). 1983. The Complete Book of Australian Mammals. Angus \& Robertson, Sydney.

Sturt, C. 1833. Two Expeditions into the Interior of Southern Australia. 2 vols. Smith, Elder \& Co., London.

Sutton, P. 1989. Postvocalic ' $r$ ' in an Australian English dialect. Aust. J. Ling., vol.9, pp.161-163.

Taplin, G. 1859-79. Journals. Mortlock Library, Adelaide.

Thomas, M. 1925. The Diary and Letters of Mary Thomas (1836-1866). Edited by Thomas, E.K. Thomas \& Co., Adelaide.

Tindale, N.B. 1937a. Tasmanian Aborigines on Kangaroo Island, South Australia. Rec. S. Aust. Mus., vol.6, pp.29-37.

Tindale, N.B. 1937b. Relationship of the extinct Kangaroo Island culture with cultures of Australia, Tasmania and Malaya. Rec. S. Aust. Mus., vol.6, pp.39-60.

Tindale, N.B. 1953. Growth of a people. Rec. Qu. Vic. Mus., vol.2, pp.1-64.

Tindale, N.B. 1974. Aboriginal Tribes of Australia: Their Terrain, Environmental Controls, Distribution, Limits, and Proper Names. Australian National University Press, Canberra. 
Tindale, N.B. and B.G. Maegraith 1931. Traces of an extinct Aboriginal population on Kangaroo Island. Rec. S. Aust. Mus., vol.4, pp.275-285.

Tolmer, A. 1882. Reminiscences of an Adventurous and Chequered Career at Home and at the Antipodes. 2 vols. Sampson Low, Marston, Searle \& Rivington, London.

Tyler, M.J., Twidale, C.R. and J.K. Ling (eds). 1979. Natural History of Kangaroo Island. Royal Society of South Australia, Adelaide.

Wells, G. E. 1978. Kangaroo Island, South Australia. Cradle of a Colony. The Earliest History and Legends of Ultima Thule: the Island at the End of the World. Island Press, Kangaroo Island.

Wilkinson, G.B. 1848. South Australia: its Advantages and Resources. London.

Wood Jones, F. 1923-1925. The Mammals of South Australia. Parts 1-3. Government Printer, Adelaide.

Wood Jones, F. 1934. Tasmanians and Australians. Man, nos.66-67, pp.52,53. 